\title{
ANALYSIS OF ALTERNATIVE ENERGY SOURCES AND THEIR USE IN THE PIG BREEDING FARM DURING THE WINTER PERIOD
}

Aleksandra MINAJEVA, Institute of Agricultural Engineering and Safety, Faculty of Agricultural Engineering, Aleksandras Stulginskis University, Studentu str. 15, Akademija, LT-53362 Kaunas distr.; Lithuania; Vilnius College of Technologies and Design, Antakalnio str. 54, Vilnius, Lithuania, a.minajeva@ vtdko.lt

\begin{abstract}
Investigations were carried out at the pig breeding farm located in Šalčininkai district. There are 9 hulls in the pig farm, two of which are dedicated to pig breeding. One barn was reconstructed: installed heated-cooled floor with the heat pump and a manure-slurry cooling system. The second barn was installed more than 50 years ago and has not been modernized yet. This hull doesn't have mechanical cooling system, is heated by a gas heater, infrared rays are installed in the pig holders. Both barns have a mechanical air exhaust system. The research data were collected during the winter season. Also was collected statistical data on the birth rate, weight gain, morbidity and piglets' death. The parameters of the old barn microclimate depended directly on outdoor air parameters. The average temperature in the old housing was $21^{\circ} \mathrm{C}$, in the modernized $27^{\circ} \mathrm{C}$; humidity was $79 \%$ and $54 \%$ respectively. In the winter period, in the old barn, due to low air temperatures and high humidity, the piglets' death was $7.8 \%$ upper and the weight gain of $35 \%$ lower than in the reconstructed barn. It has been determined that the microclimate parameters influence the growth of the weight of piglets, their fall, and morbidity. The installed heated-cooled floor and manure-slurry cooling systems allow the farm to not use other types of fuel, facilitate the maintenance of the microclimate parameters of the barn (maintenance of the design temperature all the year), reduce emissions of $\mathrm{CO}_{2}$ and $\mathrm{NH}_{3}$ into the environment, and receive higher revenues from growing and selling products.
\end{abstract}

Keywords: manure-slurry cooling system, microclimate, heat pump, livestock farm, pigs breeding, piglets weight gain.

\section{INTRODUCTION}

There are over 230 thousand farms registered in Lithuania. When Lithuania joined the EU, farmers were introduced to a number of new requirements. One of the most important strategic principles in the EU is to avoid harming environment and to produce competitive products. The Reform of the Common Agricultural Policy was launched in 2003 and aimed at improving agricultural market orientation, modernization and adaptation to rapidly changing market conditions and new challenges. This reform was continued with the help of the Communique titled The Common Agricultural Policy Towards (CAP) 2020 (The CAP Towards 2020, 2011). One of the objectives of this Communiqué was to use renewable energy resources for agriculture needs (Jurkenaite, 2011).

In order to achieve high economic results in the livestock sector, livestock should be kept in an optimal microclimate zone. The optimal microclimate zone is a range of microclimate indicators, in which the productivity of livestock is the highest, feed costs are the lowest and microclimate maintaining costs are economically feasible (Bleizgys, Cesna, 2012).

According to the Institute of Geology and Geography in Lithuania, the potential of Lithuania in geothermal energy amounts to $0.8 \mathrm{TWh}$ /year (Katinas, Markevicius, 2006). The use of geothermal energy in livestock farms would help to solve the issues of different temperature regimes for different groups of animals. A design of a geothermal heating system must also take into account an ecological coefficient of performance (ECOP) (Wouagfack, Tchinda, 2012). This is a new evaluation criterion that estimates the utility of a heat pump not only from an economic, energetic and thermodynamical, but also from an ecological point of view (Kim, et al., 2012). By cooling down the slurry channel, emissions of $\mathrm{CO}_{2}$ and $\mathrm{NH}_{3}$ could be reduced (Self, Reddy, Rosen, 2011).

The purpose of this study is to encourage farmers to use renewable energy sources in their activities, which could reduce the production price, as well as the amount of pollutants, and could ensure optimum microclimate for livestock.

\section{RESEARCH METHODS AND MICROCLIMATE INDICATORS}

A pig breeding farm located in Salcininkai District. This farm contains nine houses for pigs. Approx. 2,000 pigs for breeding are kept in the farm.

Two housing units are intended for pig breeding and piglet rearing before their weaning. One housing unit is upgraded. New pens with a heat pump are installed on the heated-cooled floor. The second building was built more than

Copyright (C) 2017 The Authors. Published by Aleksandras Stulginskis University. This is an open-access article distributed under the terms of the Creative Commons Attribution License (CC-BY 4.0), which permits unrestricted use, distribution, and reproduction in any medium, provided the original author and source are credited. 
50 years ago and has not yet been modernized. This housing is heated by gas heaters; infrared lamps are installed in the farrowing pen; no mechanical cooling systems are used. Both housing units have a mechanical air exhaust system.

A total area of a single house is $1,580.7 \mathrm{~m}^{2}$. The upgraded housing unit is divided into 3 parts, which have 270 pens -90 pens each. An old house is of the same area, divided into 2 parts, which contains 120 pens -60 pens each.

Liquid manure handling equipment is installed in the piggery. Livestock is kept on the partially grooved floor and gutters for urine and manure drainage to the collecting tanks are installed below.

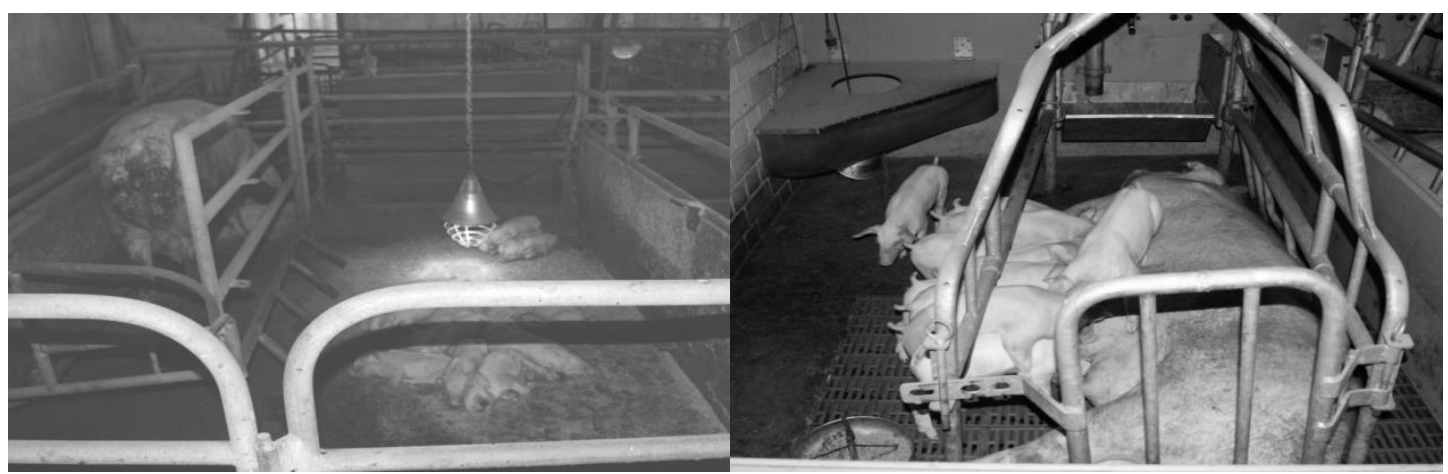

Figure 1. Old and modernized pens

Infrared heating appliances (lamps) are used for an additional heating of piglets.

In the course of the study, a systematic analysis of the object was performed, i.e. energy, economic and statistical data (diseases and deaths of piglets) was investigated.

The standard parameters of the microclimate in the piggeries are regulated by the requirements for animal husbandry technology (separate requirements - for each animal species) (Zin., 2003, No. 9-334). Taking the parameters of the standard microclimate into account animals will feel comfortable, healthy and productive; however, if the parameters of the microclimate do not meet the standards, agricultural companies and farmers will suffer economic losses due to animal diseases, reduced productivity and deaths.

The optimum air temperature in the housing of pregnant sows should be between 16 and $20^{\circ} \mathrm{C}$ for sows and $35^{\circ} \mathrm{C}$ for born piglets (the later should gradually decrease to $26^{\circ} \mathrm{C}$ in a fourth week of piglets' life). Therefore, for the first two weeks, piglets are additionally heated with infrared lamps. A cycle of the housing-use: a week before farrowing pregnant sows are brought to a relevant housing unit and then kept there until the piglet weaning day.

The maximum permissible concentration of $\mathrm{CO}_{2}$ in the air is 3,000 ppm (ZU TPT 02: 2010).

A heat pump is installed in the modernized housing for the heating of pens and the cooling of slurry. The old housing is heated by gas. The construction of the two buildings is identical. Measurements in the piggeries were performed in winter season. Indoor and outdoor air temperature, air humidity and $\mathrm{CO}_{2}$ concentration in the housing units were measured.

In the research work the following equipment for microclimate parameter testing was used for the object system observation: Temperature/relative humidity/light/external signal sensors HOBO U12-012 (resolution of the measured range - 12 bits; recording capacity - $64 \mathrm{kB}$ (40,000 records); a multifunction measuring instrument and data logger Ahlborn Almemo 2890-9; a carbon dioxide sensor FYA600CO2.

Measurements were made in both housing units at the height of 1.5 meters. The data were collected every 10 seconds.

\section{RESULTS OF THE STUDY FOR WINTER SEASON}

The parameters of the piggery microclimate and the outside air temperature were measured in January, 2014. The dependence of the air temperature in the housing units on the outside air temperature is presented in the following figures.

In winter, the air temperature in the old housing unit was directly dependent on the outside air temperature and was lower than that in the modernized piggery.

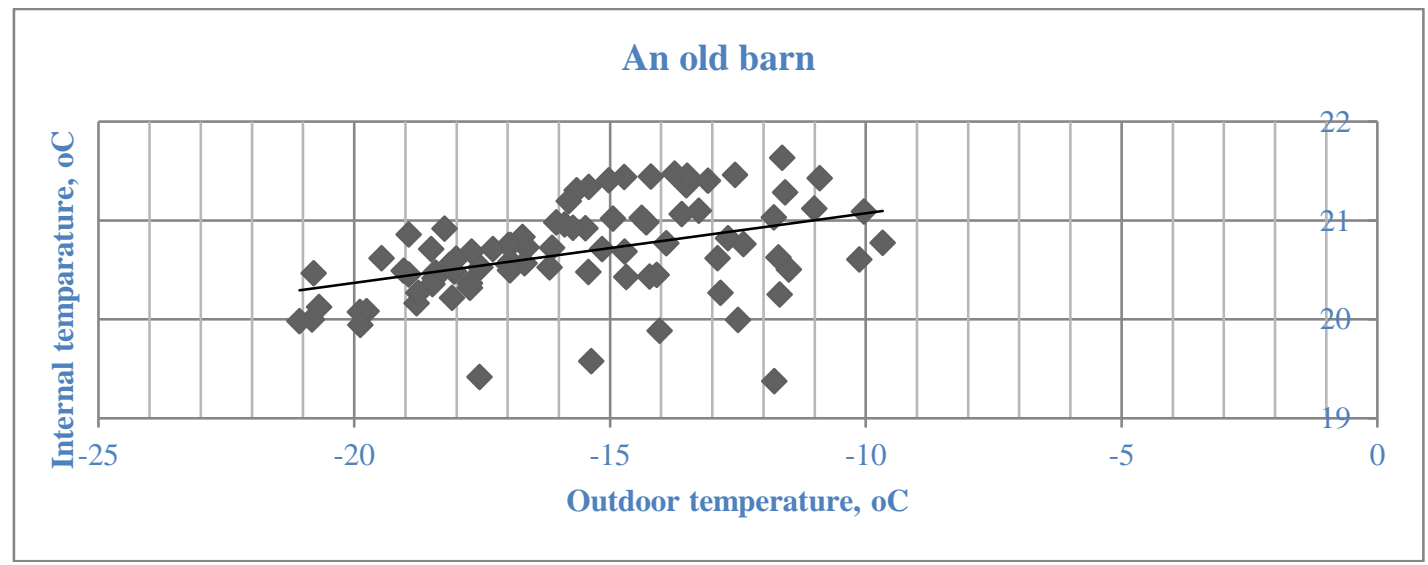

Figure 2. The air temperature in the old barn, ${ }^{\circ} \mathrm{C}$ 


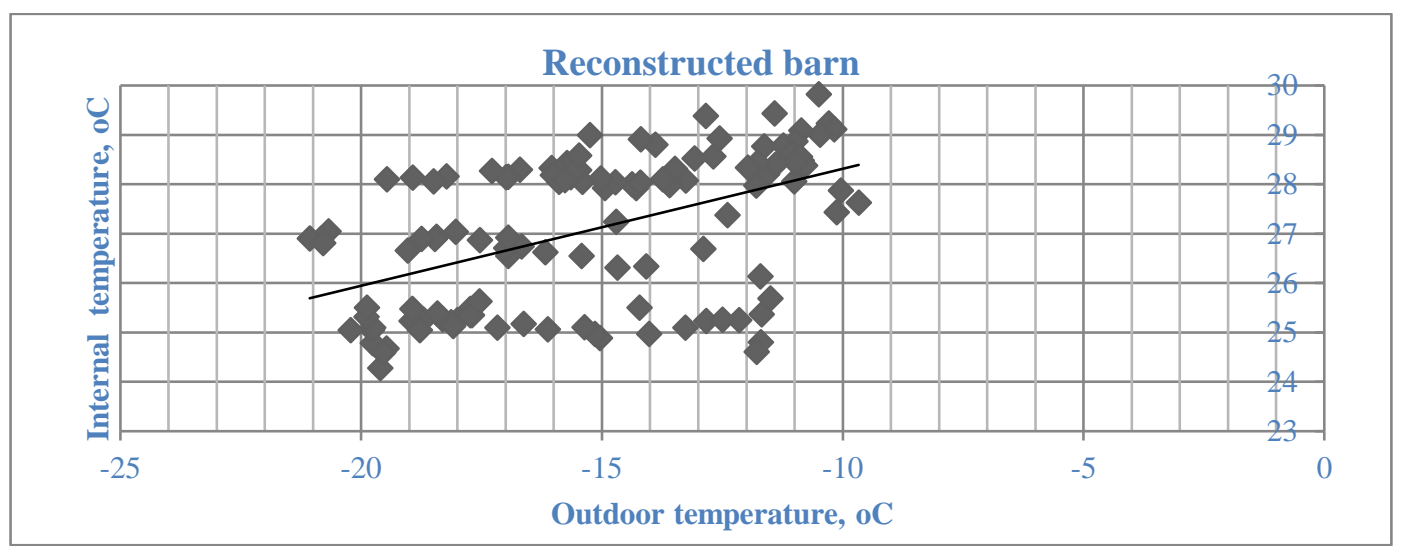

Figure 3. The air temperature in the modernized barn, ${ }^{\circ} \mathrm{C}$

The air temperature in the modernized housing unit corresponded to the requirements of the piggery technological design; however, it was also dependent on the outside air temperature.

Due to badly sealed ventilation shafts, windows and door gaps drafts were present in the old housing; therefore, $\mathrm{CO}_{2}$ did not exceed the established norms, i.e. the room was ventilated naturally.

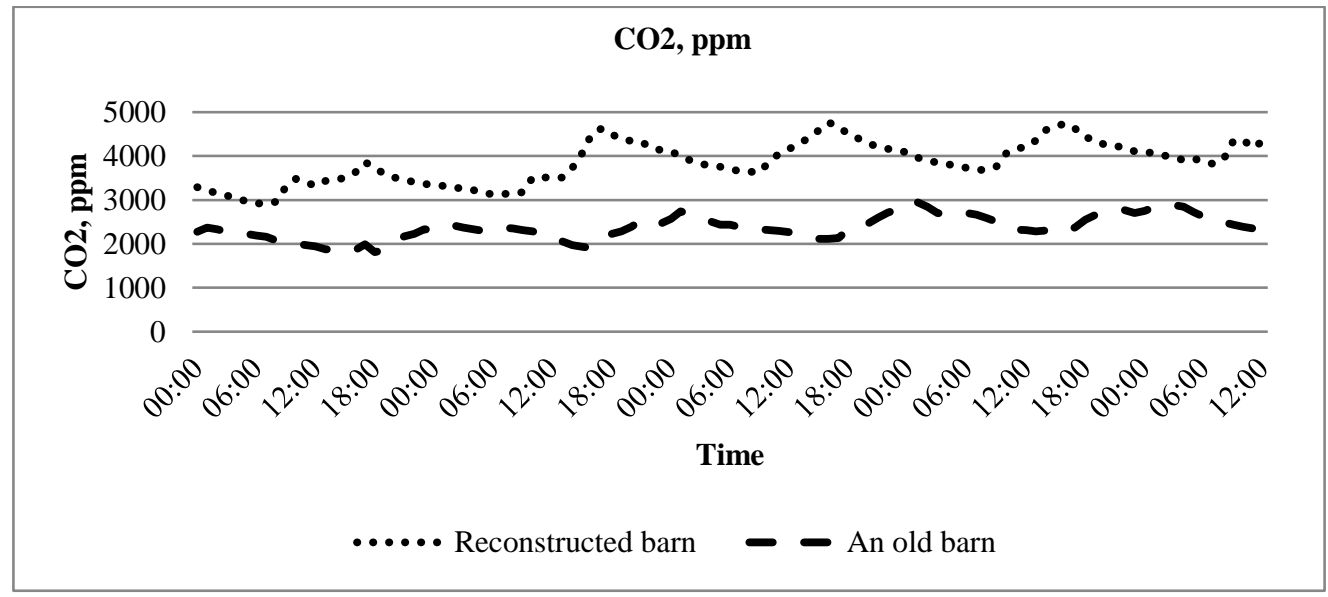

Figure 4. The $\mathrm{CO}_{2}$ concentration in the air of the old and modernized barns, ppm

In the modernized piggery, on the other hand, due to the lack of ventilation the amount of $\mathrm{CO}_{2}$ exceeded the established norms, i.e. the maximum permissible limit of 3,000 ppm.

In the old housing, due to high humidity, which exceeded the established technological standards for piggery design (50-60\%), all partitions were frosted.

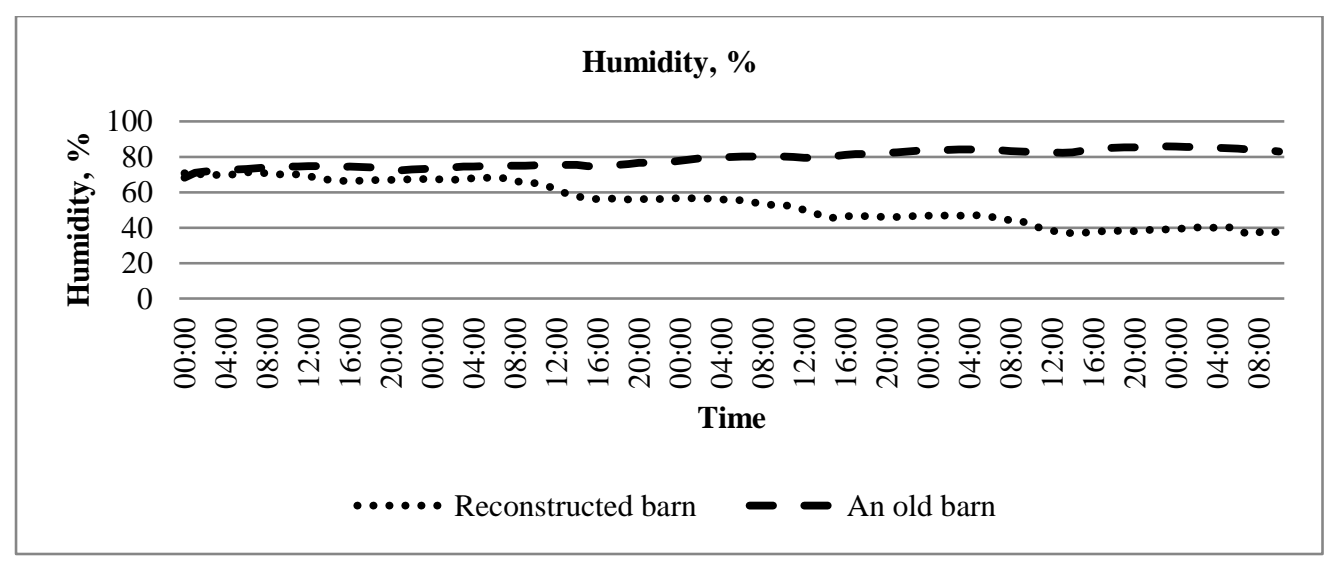

Figure 5. The humidity of the old and modernized barns

At high air temperatures the humidity indicators in the modernized housing unit were lower than the ones set in the design rules.

Having analyzed the measurement data, it has been observed that the parameters of microclimate in the old piggery were directly dependent on the parameters of the outside temperature. In the modernized piggery, the use of heat pumps 
ensured the maintenance of standard microclimate parameters, with the exception of $\mathrm{CO}_{2}$ concentration in the air exceeding the set limits. In this case, ventilation intensity should be increased.

\section{DATA OF THE STUDIED PIGLETS' DEATHS, MORBIDITY AND WEIGHT GAIN}

In order to assess the influence of microclimate on health, death and weight gain of piglets, the data on their birth rate, death and weight gain were collected. The newborn piglets have little energy; therefore, the newborn (still wet) piglets require a lot of energy to maintain a constant body temperature. For this reason the ambient air temperature has an important influence on their weight. During the study, the weight of piglets was measured on the first day of birth and at the time of their sale.

Piglets' deaths are classified according to their cause. Death is a result of various diseases, pathologies; deaths are also caused by mechanical injuries and famine - when piglets do not receive enough milk or the milk quality is poor; moreover, piglets also died when they are lied down on by pigs and suffocate (this usually happens when nest temperature is inappropriate and the piglets try to get closer to the sow).

Pregnant sows were brought to the old housing unit on January 4, 2014. In this housing unit, the farrowing period was from January 11, 2014, to January 20, 2014. During this period, 682 piglets were born. An average weight of born piglets was $1.7 \mathrm{~kg}$. During the piglet rearing (before their sale), 100 piglets died. An average weight of sold piglets was $6.2 \mathrm{~kg}$.

Pregnant sows were brought to the modernized housing unit on January 10, 2014. In this housing unit the farrowing period was from January 17, 2014, to January 28, 2014. During this period 1,048 live piglets were born. An average weight of born piglets was $1.8 \mathrm{~kg}$. During the piglet rearing (before their sale), 76 piglets died. An average weight of sold piglets was $7.2 \mathrm{~kg}$.

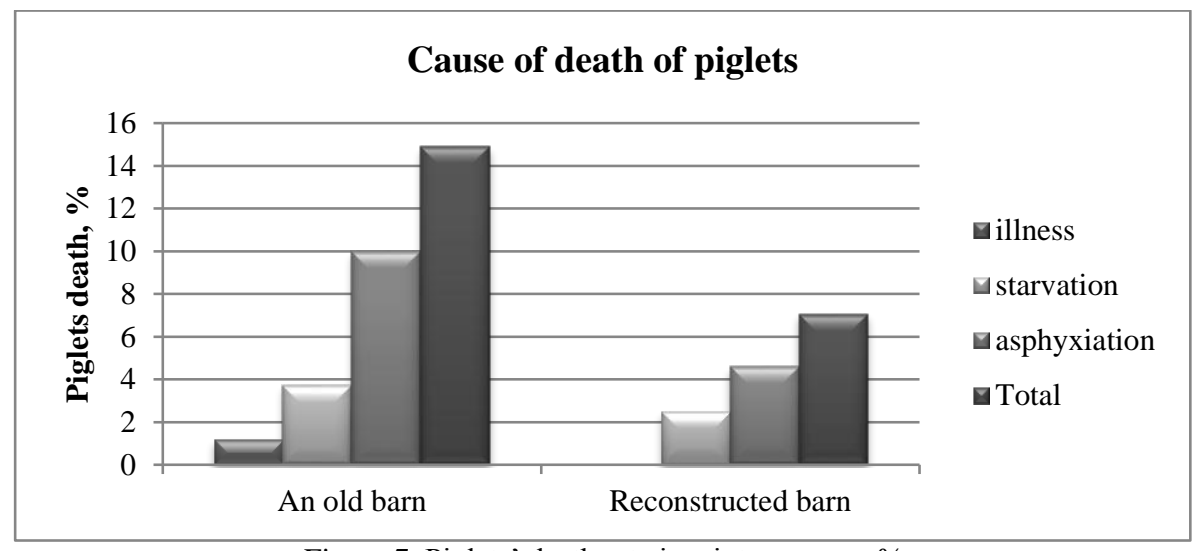

Figure 7. Piglets' death rate in winter season, \%

Due to the increased humidity in the old piggery, the piglets here were more often prone to diarrhea. Diarrhea is the most common and largely damaging disease in suckling pigs. Sick piglets grew more slowly or died eventually (Juskiene, Juska, 2001). Diarrhea in piglets is a result of a stress-inducing environment, i.e. an ambient temperature, drafts, and humidity.

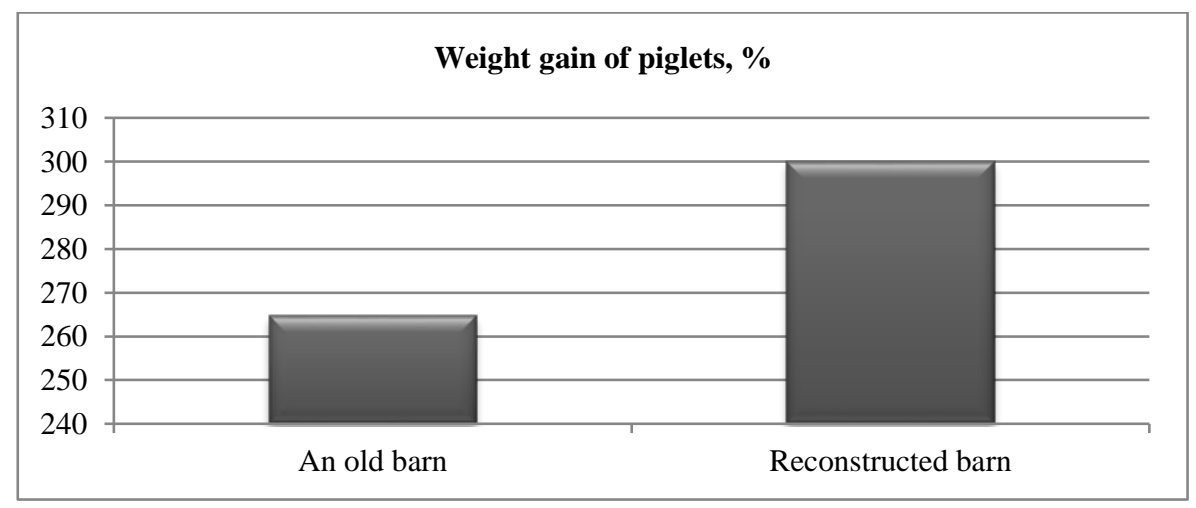

Figure 8. Piglet weight gain, $\%$

Having analyzed the microclimate in the old and modernized housing units, as well as the increase in the piglets' weight, by piggeries, it was observed that in winter season the weight gain of piglets in the old housing unit was by $35 \%$ lower than that of the piglets in the modernized housing.

Taking the difference between design air temperatures for a sow and piglets into account, the floor heating should be the best for a pen. Due to the presence of harmful gases in the air indoor heating is not suitable for the buildings of this type; moreover, it would also be difficult to provide the required temperature in the nest. Due to a large area of the building and its structure radiator heating is also not suitable as pigs can damage the pipelines and radiators themselves. The 
advantage of the floor heating is that the pen layout allows the installation of different floor heating in piglets and sows' lying area; moreover, the pipelines go under the floor; thus pigs cannot damage them.

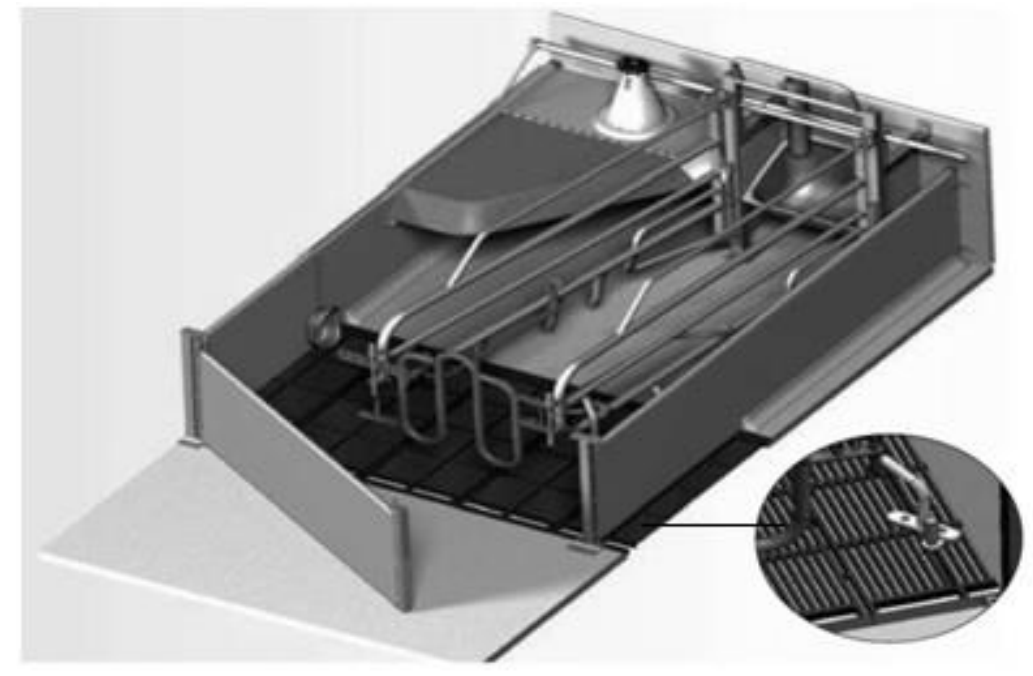

Figure 9. The scheme for the nest of a sow and piglets

Key consumption figures are taken from the account for the year 2013. According to the actual data, in 2013, the company consumed 383.5 MWh of electricity. The old piggery does not have a separate electricity meter; therefore, the energy consumption in this housing unit is calculated according to the following formula:

A number of pens (pcs.) x lamp power (W) x a number of heated days x 24 hours $\mathrm{x}$ a number of pig growth cycles per year.

120 pcs. $\times 175 \mathrm{~W}$ x 18 days $\times 24 \mathrm{~h} \times 9,125$ cycles $=82,782,000 \mathrm{Wh}=82.8 \mathrm{MWh}$

Upgrading of the old housing unit would result in the use of infrared lamps on the first 4 days following the piglets' birth; therefore, the energy consumption is calculated according to the following formula:

A number of pens (pcs.) x lamp power (W) x a number of heated days x 24 hours $\mathrm{x}$ a number of pig growth cycles per year.

120 pcs. $\times 175 \mathrm{~W}$ x 4 days $\times 24 \mathrm{~h}$ x 9,125 cycles $=18,396,000 \mathrm{Wh}=18.4 \mathrm{MWh}$. The savings would amount to 64.4 MWh per year.

Natural gas is only used for the heating of four piggeries. They have 11 natural gas burners. In the modernized housing unit, however, natural gas is not used, and the heat is produced by the installed manure-slurry cooling heat pump. According to the actual data, in $2013,25,720 \mathrm{~m}^{3}$ of gas was used for the piggery heating.

After the upgrading of the old housing unit natural gas could be replaced by heat-generated manure-slurry cooling technology ("heat pump") and its use could result in saving up to $6,430 \mathrm{~m}^{3}$ of gas.

\section{CONCLUSIONS}

1. The piggery microclimate parameters of the pig breeding farm were measured in winter season. The old and modernized housing units were examined. Statistical data on the birth rate, weight gain, morbidity and death of piglets were also collected.

2. The air temperature in the old housing unit was directly dependent on the outside air temperature. The average temperature in the old piggery was $21^{\circ} \mathrm{C}$, that in the modernized piggery $-27^{\circ} \mathrm{C}$, while the humidity was $79 \%$ and $54 \%$, respectively.

3. Due to badly sealed ventilation shafts, windows and door gaps drafts were present in the old housing; therefore, $\mathrm{CO}_{2}$ did not exceed the established norms, i.e. the room was ventilated naturally. In the modernized piggery, on the other hand, due to the lack of ventilation the amount of $\mathrm{CO}_{2}$ exceeded the established norms, i.e. the maximum permissible limit of 3,000 ppm.

4. In the old housing unit, due to low air temperature and high humidity, a $7.8 \%$ higher morbidity rate and $35 \%$ lower weight gain in piglets than compared to those in a modern piggery were recorded.

5. It has been determined that microclimate parameters have an influence on the weight gain, death and morbidity of piglets. The installed floor heating, cooling and manure-slurry cooling systems, as well as mechanical ventilation, allow the farm to refrain from using other types of fuels, to easier ensure the parameters of the microclimate in the piggery, to reduce $\mathrm{CO}_{2}$ and $\mathrm{NH}_{3}$ emissions to the environment, and to receive higher incomes in growing and selling the products.

\section{REFERENCES}

1. Bleizgys R., Čèsna J. 2012. Gyvūlininkystès technologijų inžinerija. ASU, ISBN 978-609-449-018-7.[In Lithuanian]

2. Europos parlamentas. 2011,,Bendroji žemès ūkio politika artėjant 2020m" komunikatas. .[In Lithuanian] 
3. Jurkėnaitè, N. 2011. Bendroji žemės ūkio politika artejant 2020 m.: evoliucija ar revoliucija? Ekonomika ir vadyba: aktualijos ir perspektyvos, 2011, Vol. 4, No. 24, pp. 42-50.[In Lithuanian]

4. Juškienè V., Juška R. 2001. Energiją taupantys kiaulių laikymo būdai. Gyvulininkystès tvarkymas: laikmečio aktualijos (mokslinès-gamybinès konferencijos pranešimai). Baisogala, 2001. pp. 73 - 81. .[In Lithuanian]

5. Katinas, V., Markevicius, A. 2006. Promotional policy and perspectives of usage renewable energy in Lithuania. Energy Policy, Vol. 34, pp. 771-780. https://doi.org/10.1016/j.enpol.2004.07.011

6. Kim J, et al., 2012. Experimental study of operating characteristics of compression/absorption high-temperature hybrid heat pump using waste heat. Renewable Energy, Vol. 54, pp. 12-19. https://doi.org/10.1016/j.renene.2012.09.032

7. Lietuvos Respublikos valstybinè maisto ir veterinarijos tarnyba. Kiaulių laikymo reikalavimai, patvirtinti Valstybinės maisto ir veterinarijos tarnybos įsakymas $\mathrm{Nr} 387$ (Žin.,2003, Nr 9-334). .[In Lithuanian]

8. Lietuvos Respublikos valstybinè maisto ir veterinarijos tarnyba. 2008.Ūkinių gyvūnų gerovè Lietuvoje. .[In Lithuanian]

9. Peters J. 2003. Recommended Methods of Manure Analysis. University of Wisconsin, Madison, WI: Cooperative Extension Publishing.

10. Self, S.J., Reddy, B.V, Rosen, M.A. 2011. Geothermal heat pump systems: Status review and comparison with other heating options. Applied Energy, Vol. 101, pp. 341-348. https://doi.org/10.1016/j.apenergy.2012.01.048

11. Teye F. K., Hautala M., 2010. A comparative assessment of four methods for estimating ammonia emissions at microclimatic locations in a dairy building. International Journal of Biometeorology, 54: 63-74.https://doi.org/10.1007/s00484-009-0255-y

12. Vaičionis, G. 2013. Ūkiuose sukaupiamo mëšlo ir srutų kiekio apskaičiavimas. Gyvulininkystès žinynas, Pieno ūkis. .[In Lithuanian]

13. Vrankn E et al., 2002. Infuence of climate control on the ammonia emission of pig houses. Proceedings of the $10^{\text {th }}$ international Conference of the RAMIRAN network. Strbske Pleso, High Tatras, Slovak republik, pp. 215-218

14. Wouagfack, P.A.N., Tchinda, R. 2012. The new thermo-ecological performance optimization of an irreversible three-heat-source absorption heat pump. International Journal of Refrigeration, Vol. 35, Iss. 1, pp. 79-87. ps://doi.org/10.1016/j.ijrefrig.2011.09.008

15. Žemès ūkio ministerija. 2010. Kiaulidžių technologinio projektavimo taisyklès. Vilnius. ŽŪ TPT 02:2010. [In Lithuanian] 